\title{
Screen or not to screen? 7 questions in prevention of infection from refugees and migrants
}

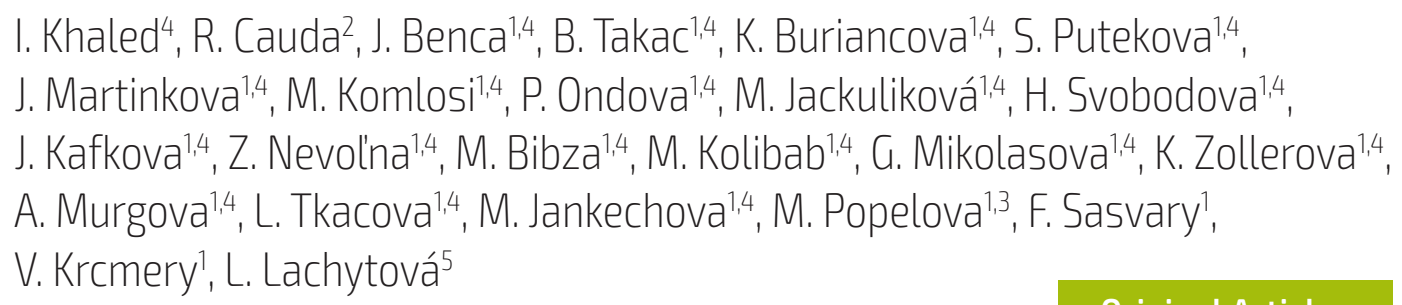

Original Articles

${ }^{1}$ St. Elizabeth University, PhD and MSc Program Bratislava, Slovakia

${ }^{2}$ Universita Cattolica Del Sacro Cuore, Instituto Clinica Malattie Infettive, Rome, Italy

3 St. Bakhita and Rafael Clinic Mihango, Nairobi, Kenya

${ }^{4}$ UNHCR Camp, St. Elizabeth University Health Posts, Alexandropolis, Greece

${ }^{5}$ Internatioal School of Management ISM in Presov, Slovakia

\section{Correspondence to:}

St. Elizabeth University, MSc and PhD Program, Dept. of Public Health, Nám. 1. Mája č. 1, 81000 Bratislava, Slovakia

Submitted: 10.6 .2016

Revised: 11.8 .2016

Accepted: 13.9.2016

\section{Reviewers:}

R. Lanetti

Slovak Tropical Institute, SEU of Health and Social Sciences, Bratislava, Slovakia

V. Okoth

Adjunct lecturer Catholic University of Eastern Africa, Nairobi, Kenya

\section{Key words:}

Screening, Migrants.

\section{Key message:}

Migrants from Africa to EU have to be screened at least for HIV, HBV, HCV and malaria and vaccination history.

CSWHI 2016; 7(3): 16-18; DOI 10.22359/cswhi_7_3_04 @ 2016 Clinical Social Work and Health Intervention

\section{Abstract:}

Introduction: The aim of this paper was to review the preventive strategies for screening of commonest infections in migrants. Germany, UK, France, Spain and Italy have highest numbers 25 mil migrants $(31 \%$ of global migrant population ) $70 \%$ from EE and North Africa 1.9 million per year illegally, eg. Italy 250,000, Spain 200,000, Turkey 200,000/ 
year. To protect the EU from TB, HIV, HB, RTI, and possibly malaria and vaccination - preventable ID (RTD) we have to screen at least migrants and refugees. The question is about international travelers or internally displaced due to catastrophe, genocide or civil war, where similarly important as screening is the determination of vaccination status. Methods: Our and others experience on screening of migrants via the Mediterranean route versus Balkan route plus own experience from health posts in Hungary, Slovenia, Austria, Greece, Lebanon, Italy is presented. Results: Proposals for screening of ID are presented for health posts for $\mathrm{HIV}, \mathrm{HBV}, \mathrm{HCV}, \mathrm{TB}$, malaria as baseline for possible guidelines for migrants refugees screening.

Conclusion: Screening of selected ID (TB, HIV, HW, HBV, Malaria) and vaccination status in migrants and refugees to EU from Africa is mandatory.

\section{Introduction: Seven (7) questions in Migrant Health: Who, why, what, when, where, and who will pay?}

- Who should be screened? Migrants, refugees, international travelers? Internally displaced? (Tab.1)

- Why are we screening? To prevent the transmission of TB, HIV, HB, HCV etc. to EU

- What do we screen? TB, HIV, Hepatitis B, C (Malaria? Helmints?) (Tab. 2)

- When and how quick do we screen? On site or in quarantine + quick rapid diagnostic tests (Tab.3)

- Where to be screened - compulsory in quarantine. Voluntary in open detection (Tab. 4)

- Who will pay? WHO, EU, grants, UNHCR (Tab. 5)

\section{Tab. 1}

\section{Who should be screened}

1) International travelers from tropics - no

2) Migrants - yes

3) Refugees - yes

4) Internally displaced - no

5) Adoptees - yes
Tab. 2

What to screen:

TB, Hepatitis, HIV, Malaria, Vaccination status (at least)

- Respiratory diseases in low income migrants, who are afraid of admission to the hospital $50 \%$ of migrants in UK have TB, that is why UK has the highest prevalence of TB in EU

- Norway, UK, Switzerland - from 3m they apply for residence

- Easiest screening - anamnesis, PPD (Mantoux), questionnaire, Gene-XPert gene RIF TB

- Vaccinate all for MMR 1x, DTP 1x, Hepatitis $\mathrm{B}$, if vaccination status unknown

- Openness to health services for unsecured migrants: most EU are opened or semi-opened

- Emerging - all, other Greece and Germany offer only partial protection, Poland and Spain - full protect

- Other EU member states- free

Tab. 3

\section{Where do we screen:}

10 Upon arrival or in quarantines

Questions for anamnesis in Refugees to screen ID at arrival: 
- Fever - Housing Refugees,

- Sweets - 5 liter water per day,

- Weight Loss - Food 1 x day,

- Cough - Housing

- Contacts - Contacts with TB home, school

- Status of vaccination - Basic vaccine (DTP + MMR/1 x)

- Diarrhea - Latrines 1 per 50 - 100

- Hemoptysis - Managing dead bodies

\section{Tab. 4}

\section{Where to be screened?}

Rapid tests available for screening: upon arrival or in quarantine (1M):

HIV - yes - 2 min.

TB - yes (Mantoux, GeneXpert) - $20 \mathrm{~min}$.

$\mathrm{HCV}$ - yes - $20 \mathrm{~min}$.

HBV - yes - 5min.

Malaria - yes - $2 \mathrm{~min}$.

\section{Tab. 5}

\section{Who will pay:}

Access to healthcare in migrants

- about 20 million people in EU who are not European citizens

- Top 7 - Syria, Iraq, Afghanistan, Eritrea, Libya,

- Multi-cultural

- human risks, viral to bacterial infections

- establish for public health,

- equity in Health care (treat everybody).

- Full access - PT, SP, CU, FR, NL (IT, UK, BG - partial access), Turkey - free access

- No or limited Access - Germany, Greece, East Europe, none.

- EC Council 2003/T/EC from 27.1.2003 (Council Direction): "Asylum seekers must be asked to receive full assistance including Healthcare, including basic food and housing"

\section{Conclusions}

Turkish action is an example for Refugees/ Migrants Post Emergency - "Turkish" Example (TE): Syrian/Iraqi conflict generated:

- 6 million refugees, $24 \%$ war refugees, $11 \%$ asylum seekers, 35\% migrants, 30\% IDPT. Do not ask: Who is a refugee? (Who must cross border because of discrimination etc.). Just look and help (action)

- Turkey took 3 million, Iran 0.5 million, AFAD (Turkish Republic Disaster Emergent Migrant Directable charte) Lebanon 1.5 mil., Germany 1.2 mil., UK 250,000, IT 250,000, other EU 300.

\section{References}

1. PRESTILEO T, DI LORENZO F, CORRAO S: Infectious Diseases among African irregular migrants in Italy. Just an individual problem? Clin. Soc. Work 2015, 5, 45

2. KRCMERY, V., KALAVSKY, E.: Antibiotic Resistance in "ATB free" environment. In Neuroendocrinology Letters, 2007, 28, 83, p. 33-34.

3. FAVILA ESCOBIO, JOTA ECHEVARRIA, SILVIA RUBAKI, VIRAG VINICZAI: Health assistance of displaced people along the Balkan route, Lancet 2015, 386, Dec. 19, 2475

4. WICZMANDYOVA, D., TKACOVA, L., MURGOVA, A.: Proceedings Slov. Med. Univ.: The Socio Economic aspect of Migration of Nurses, ISBN 978-80-89352-470, pp. 62-70

5. WICZMANDYOVA D, MURGOVA A, The life of diabetics, life with diabetes, Book Clear Michalovce ISBN 978-809711629255.2012 , pp. 67

6. SILHAROVA B, SUVADA J, FRANEKOVA M, NOGE A, MIKOLASOVA G: Malaria in hyperendemic region, Neuroendcrinology Letters. 34, 2013, s1 38-43 